\title{
Strategi Layanan Bimbingan Dan Konseling Dalam Pengembangan Nilai Karakter Religius
}

\author{
${ }^{1}$ Nindiya Eka Safitri, ${ }^{2}$ Sitti Ummi Novirizka Hasan \\ ${ }^{1}$ Bimbingan dan Konseling, Universitas Ahmad Dahlan Yogyakarta \\ ${ }^{2}$ Bimbingan dan Konseling, SMA Negeri 1 Tidore Kepulauan \\ Email: nindiya1315001306@webmail.uad.ac.id
}

\begin{abstract}
Abstrack: Artikel ini bertujuan untuk menguraikan gagasan tentang strategi layanan bimbingan dan konseling dalam pengembangan nilai karakter religius. Karakter religius sangat dibutuhkan oleh para peserta didik untuk menghadapi degradasi moral, agar mereka mampu memiliki dan berperilaku dengan ukuran baik dan buruk yang didasarkan pada ketentuan dan ketetapan agama. Peran bimbingan dan konseling sebagai layanan psikoedukatif sekaligus sebagai bagian integral pendidikan karakter di sekolah sangat dibutuhkan dalam pengembangan karakter religius. Strategi layanan bimbingan dan konseling yang dapat diberikan adalah layanan dasar berupa kegiatan asesmen kebutuhan layanan, bimbingan klasikal, bimbingan kelompok, dan penggunaan media inovatif; layanan responsif berupa konseling kelompok dan konseling individu, serta layanan dukungan sistem berupa kolaborasi antara guru bimbingan dan konseling dengan guru agama, tokoh agama dan orangtua, serta adanya penelitian tentang karakter religius oleh guru bimbingan dan konseling. pengembangan karakter religius tidak semuanya melibatkan siswa tetapi juga memperhatikan kondisi lingkungan dan masyarakat sekitar.
\end{abstract}

Kata kunci: bimbingan dan konseling, pendidikan karakter, religius

\begin{abstract}
This article aims to describe the strategy of guidance and counseling services to development of the value of religious character. Character of religious desperately needed by the students to face the moral degradation, in order to they were able to have and behave with good and bad measure based on the provisions and statutes religion. The role of guidance and counseling as well as a service psychoeducative integral part of character education in schools is needed in the development of religious character. Strategy of guidance and counseling services that can be provided is a basic service such as the assessment of service needs, guidance classical, group counseling, and the use of innovative media; responsive service in the form of group counseling and individual counseling, as well as system support services in the form of collaboration between teacher guidance and counseling with religious teachers, religious leaders and parents, as well as the lack of research on the religious character by the teacher guidance and counseling. Religious character development do not all involve students but also pay attention to the surrounding environment and communities.
\end{abstract}

Keyword: guidance and counseling, character education, religious

\section{PENDAHULUAN}

Secara ideal tujuan pendidikan di Indonesia sebagaimana tercantum dalam Undang-Undang nomr 20 tahun 2003 tentang Sitem Pendidikan Nasional pasal 3 yaitu "Pendidikan Nasional berfungsi mengembangkan kemapuan dan membentuk watak serta peradaban bangsa yang bermartabat dalam rangka mencerdaskan kehidupan bangsa bertujuan untuk berkembangnya potensi peserta didik agar menjadi manusia yang beriman dan bertakwa kepada Tuhan Yang Maha Esa, berakhlak mulia, sehat, berilmu, cakap, kreatif, mandiri dan menjadi warga negara yang demokratis serta bertanggung jawab". Melalui 
pendidikan, peserta didik dituntun untuk mengembangkan potensi yang dimilikinya agar menjadi pribadi yang matang secara intelektual, jasmani, sosial, dan emosional.

Amanah Undang-Undang nomor 20 tahun 2003 tersebut mengisyaratkan bahwa dengan pendidikan dapat membentuk insan Indonesia yang cerdas, berkepribadian serta berkarakter sehingga nantinya akan lahir generasi bangsa yang tumbuh berkembang dengan karakter yang bernafas nilai-nilai luhur bangsa serta agama (Bhakti CP, Hasan SUN, et.al, 2015 ; 204).

Namun, pada kenyataannya dari waktu ke waktu menunjukkan bahwa dekadensi moral anak bangsa semakin terlihat seperti terjadinya penyalahgunaan narkoba, pelecehan seksual, bullying, tawuran, dan lain-lain. Hingga November 2015 pengguna narkoba di Indonesia mencapai 5,9 juta jiwa dan setiap hari ada $30-40$ orang meninggal karena narkoba (kompas,2016). Selain itu berdasarkan berita yang dilansir pada http://poskotanews.com/ pada tanggal 27 Mei 2012, hasil penelitian yang dilakukan oleh Universitas Indonesia dan Australian National University pada tahun 2010, sebanyak 20,9 persen remaja putri di Indonesia telah hamil diluar nikah karena hubungan seks dan 38,7 persen telah mengalami pernikahan dini. Kehamilan yang tidak dinginkan memicu tingginya angka aborsi di Indonesia yang mencapai angka 2,5 juta pertahun. Pada tahun 2013 laporan dari Australian Consortium For In Country Indonesian Studies yang dilansir pada cnnindonesia.com/nasional pada tanggal 29 Oktober 2014 menunjukkan hasil penelitian di 10 kota besar dan 6 kabupaten di Indonesia terjadi $43 \%$ aborsi per 100 kelahiran hidup. Aborsi tersebut dilakukan oleh perempuan di perkotaan sebesar $78 \%$ dan perempuan di pedesaan sebesar $40 \%$.

Berdasarkan fenomena yang terjadi di atas, menunjukkan bahwa terjadinya degradasi moral khususnya para generasi bangsa. Hal ini berarti belum tercapainya tujuan pendidikan sebagaimana tercantum dalam Undang-Undang nomor 20 tahun 2003 tentang Sistem Pendidikan Nasional untuk mewujudkan pribadi peserta didik yang beriman, bertakwa dan berakhlak mulia. Seiring dengan hal tersebut, gagasan mengenai pendidikan karakter mulai digencarkan untuk mencapai tujuan pendidikan Indonesia guna mewujudkan manusia seutuhnya yang berpegang teguh pada nilai-nilai keagamaan dan kemasyarakatan. Hingga pada akhir-akhir ini dunia pendidikan di Indonesia sedang digencarkan dengan kebijakanan dinamika perkembangan kurikulum 2013.

Kurikulum 2013 yang bermula dari kebijakan umum nawacita yang tertuang pada Rencana Pembangunan Jangka Menengah Nasional (RP JMN) 2015-2019 yaitu (a) meningkatkan kualitas hidup manusia Indonesia, (b) melakukan revolusi karakter bangsa, (c) meningkatkan produktivitas rakyat dan daya saing di pasar internasional, dan (d) memperteguh kebhinekaan dan memperkuat restorasi sosial Indonesia. Hal ini didukung dengan arah kebijakan pendidikan dan kebudayaan yang memiliki visi mewujudkan insan serta ekosistem pendidikan dan kebudayaan yang berkarakter dengan berlandaskan gotong royong (Dit, Pembinaan SMA, Ditjen Pendidikan Dasar dan Menengah, 2017).

Secara eksplisit, pengembangan karakter menjadi salah satu focus dalam kurikulum 2013 khususnya dinamika perkembangannya dalam 2 tahun terakhir. Sutisna, dkk $(2017 ; 1)$ menyatakan bahwa dalam pelaksanaan kurikulum 2013 di tahun 2017 terdapat sejumlah isu aktual salah satunya yaitu penguatan pendidikan karakter. Penguatan Pendidikan Karakter (PPK) telah disusun oleh pemerintah dan telah dituangkan dalam bentuk Peraturan Menteri Pendidikan dan Kebudayaan nomor 23 tahun 2015. Ada lima nilai karakter yang hendak diperkuat dalam implementasi kurukulum 2013 saat ini, salah satunya yaitu nilai karakter religius. Nilai karakter religius merupakan poin pertama karakter yang diperkuat sebelum nilai nasionalisme, mandiri, gotong royong dan integritas. Hal ini dikarenakan karakter religius sangat dibutuhkan oleh para peserta didik untuk menghadapi perubahan zaman dengan gambara degradasi moral, dalam hal ini diharapkan peserta didik mampu memiliki dan berperilaku dengan ukuran baik dan buruk yang didasarkan pada ketentuan dan ketetapan agama (E-learning Pendidikan, 2011)

Bimbingan dan Konseling sebagai salah satu bagian integral dari sistem pendidikan memiliki peran penting dalam pengembangan karakter khususnya nilai karakter religius di sekolah. Pentingnya peran guru BK ditegaskan dalam ASCA (American School Counselor Association), 2011 bahwa : 
"Professional counselor need to take an active role in initiating, facilitating, and promoting character, education programs in the school curriculum. The professional school counselor as a part of the school community and as a highly resourceful person, takes an active role by working cooperatively with teachers and administration in providing character education in the school as an integral part of the school curriculum and activities"

Konselor sekolah sebagai salah satu stake holder di sekolah memiliki peran penting untuk mengembangkan karakter peserta didik. Pengembangan karakter khususnya nilai karakter religius dapat dilakukan melalui kegiatan layanan bimbingan dan konseling dari perencanaan hingga ke tahap evaluasi. Dengan demikian diharapkan peserta didik dapat mengimplementasikan nilai karakter religius dalam kehidupannya sehari-hari.

\section{PEMBAHASAN}

\section{A. Hakikat Karakter Religius}

Kata dasar dari religius adalah religi yang berasal dari bahasa asing religion sebagai bentuk dari kata benda yang berarti agama atau kepercayaan akan adanya sesuatu kekuatan kodrati di atas manusia. Sedangkan religius berasal dari kata religious yang berarti sifat religi yang melekat pada diri seseorang. Religius sebagai salah satu nilai karakter dideskripsikan oleh Suparlan sebagai sikap dan perilaku yang patuh dalam melaksanakan ajaran agama yang dianut, toleran terhadap pelaksanaan ibadah agama lain, dan hidup rukun dengan pemeluk agama lain. Karakter religius ini sangat dibutuhkan oleh siswa dalam menghadapi perubahan zaman dan degradasi moral, dalam hal ini siswa diharapkan mampu memiliki dan berprilaku dengan ukuran baik dan buruk yang di dasarkan pada ketentuan dan ketetapan agama (E-Leraning Pendidikan, 2011).

Religius sebagai salah satu nilai dalam pendidikan karakter dideskripsikan oleh Kemendiknas (2010: 27) sebagai sikap dan perilaku yang patuh dalam melaksanakan ajaran agama yang dianut, toleran terhadap pelaksanaan ibadah agama lain, dan hidup rukun dengan pemeluk agama lain. Selanjutnya, Ngainum Naim (2011: 124) mengungkapkan bahwa nilai religius adalah peghayatan dan implementasi dari ajaran agama dalam kehidupan sehari-hari. Berdasarkan beberapa pendapat dari para ahli dapat disimpulkan bahwa nilai religius merupakan nilai yang bersumber dari ajaran agama yang dianut sesorang yang dilaksanakan dalam kehidupannya sehari-hari.

Glok dan Stark dalam Lies Arifah (2009:

12) membagi aspek religius dalam lima dimensi sebagai berikut:

a. Religious belief (aspek keyakinan), yaitu adanya keyakinan terhadap Tuhan dan segala sesuatu yang berhubungan dengan dunia gaib serta menerima hal-hal dogmatik dalam ajaran agamanya. Keimanan ini adalah dimensi yang paling mendasar bagi pemeluk agama.

b. Religious practice (aspek peribadatan), yaitu aspek yang berkaitan tingkat keterikatan yang meliputi frekuensi dan intensitas sejumlah perilaku, dimana perilaku tersebut sudah ditetapakan oleh agama seperti tata cara menjalankan ibadah dan aturan agama.

c. Religious felling (aspek penghayatan), yaitu gambaran bentuk perasaan yang dirasakan dalam beragama atau seberapa jauh seseorang dapat menghayati pengalaman dalam ritual agama yang dilakukannya misalnya kekhusyukan ketika melakukan sholat.

d. Religious knowledge (aspek pengetahuan), yaitu aspek yang berkaitan dengan pemahaman dan pengetahuan seseorang terhadap ajaran-ajaran agamanya untuk menambahkan pengetahuan tentang agama yang dianutnya.

e. Religious effect (aspek pengamalan), yaitu penerapan tentang apa yang telah diketahuinya dari ajaran-ajaran agama yang dianutnya kemudian diaplikasikan melalui sikap dan perilaku dalam kehidupan seharihari.

\section{B. Konsep Dasar Bimbingan dan Konseling}

Bimbingan, sebagai upaya pendidikan, diartikan sebagai proses bantuan kepada individu untuk mencapai tingkat perkembangan diri secara optimum di dalam navigasi hidupnya secara mandiri. Bantuan dalam arti bimbingan yaitu memfasilitasi individu untuk mengembangkan kemampuan memilih dan mengambil keputusan atas tanggung jawab 
sendiri. Kondisi perkembangan optimum adalah kondisi dinamis yang ditandai dengan kesiapan dan kemampuan individu untuk memperbaiki diri (self-improvement) agar dia menjadi pribadi yang berfungsi penuh (fully-fungctioning) di dalam lingkungannya (Sunaryo Kartadinata, 2011:57). Sedangkan, tujuan utama layanan bimbingan dan konseling di sekolah adalah memberikan dukungan pada pencapaian kematangan kepribadian, keterampilan sosial, kemampuan akademik, dan bermuara pada terbentuknya kematangan karir individual yang diharapkan dapat bermanfaat di masa yang akan datang (Fatur Rahman, 2009:4).

Dalam Depdiknas (2008) dijelaskan bahwa pada saat ini telah terjadi perubahan paradigma pendekatan bimbingan dan konseling, yaitu dari pendekatan yang berorientasi tradisional, remedial, klinis, dan terpusat pada konselor, kkepada pendekatan yang berorientasi perkembangan dan preventif. Pendekatan bimbingan dan konseling perkembangan (Developmental Guidance and Counseling) atau bimbingan dan konseling komprehensif (Comprehensive Guidance and Counseling) didasarkan pada upaya pencapaian tugas perkembangan, pengembangan potensi, dan pengentasan masalah-masalah konseli. Pendekatan bimbingan dan konseling perkembangan ini kemudian dikenal dengan bimbingan dan konseling komprehensif.

Menurut Supriatna (2011), bimbingan dan konseling komprehensif merupakan model bimbingan dan konseling yang berpegang pada prinsip bimbingan dan konseling perkembangan. Bimbingan dan konseling perkembangan bertolak dari asumsi bahwa perkembangan yang sehat terjadi melalui interaksi yang sehat antara individu dengan lingkungannya. Ini berarti bahwa pengembangan lingkungan perkembangan atau ekologi perkembangan manusia merupakan wahana strategis perkembangan siswa yang harus dikembangkan konselor. Lingkungan perkembangan adalah lingkungan belajar yang terstruktur dan secara sengaja dirancang untuk memberi peluang kepada siswa mempelajari perilaku baru, membentuk ekspektasi dan persepsi, memperbaiki dan bahkan mengganti perilaku yang tidak sesuai, memperhalus dan menginternalisasi perilaku. Dalam Permendikbud Nomor 111 Tahun 2014 tentang Pelaksanaan Bimbingan dan Konseling Pada Pendidikan Dasar dan Menengah, dijelaskan bahwa bimbingan dan konseling komprehensif terdiri dari 4 (empat) komponen layanan, yaitu layanan dasar, layanan peminatan dan perencaaan individual, layanan responsif dan dukungan sistem.

Layanan Dasar, sebagai pemberian bantuan melalui kegiatan penyiapan pengalaman terstruktur secara klasikal atau kelompok yang dirancang dan dilaksanakan secara sistematis dalam rangka mengembangkan kemampuan penyesuaian diri yang efektif sesuai dengan tahap dan tugas perkembangan. Strategi layanan dasar yaitu 1) bimbingan klasikal, 2) bimbingan kelompok, 3) media bimbingan kelompok, 4) asesmen kebutuhan. Layanan Peminatan dan Perencanaan Individual, sebagai bantuan untuk merumuskan dan melakukan aktivitas-aktivitas sistematik yang berkaitan dengan perencanaan masa depan berdasarkan pemahaman tentang kelebihan dan kekurangan dirinya, peluang dan kesempatan yang ada di lingkungan. Stetategi layanan perencanaan individual dan peminatan berupa layanan peminatan dalam format individu maupun kelompok untuk membantu siswa merecanakan pendidikan lanjutan serta perencanaan karir. Sedangkan, layanan responsif, sebagai proses bantuan untuk menghadapi masalah dan memerlukan pertolongan dengan segera, supaya peserta didik tidak mengalami hambatan dalam pencapaian tugas-tugas perkembangan. Strategi layanan responsif dapat berupa konseling individu, konseling keleompok, dan lain sebagainya. Selanjutnya, dukungan sistem diartikan sebagai proses bantuan atau fasilitasi atau dukungan secara tidak langsung terhadap kelancaran, efektivitas dan efisisen pelaksanaan layanan bimbingan dan konseling.

\section{Strategi Layanan Bimbingan dan Konseling Dalam Pengembangan Karakter Religius}

Karakter religius sangat dibutuhkan oleh para peserta didik untuk menghadapi degradasi moral, agar mereka mampu memiliki dan berperilaku dengan ukuran baik dan buruk yang didasarkan pada ketentuan dan ketetapan agama. Akhmad Muhaimin Azzet (2011: 88) hal yang semestinya dikembangkan dalam diri siswa adalah terbangunnya pikiran, perkataan, dan tindakan siswa yang diupayakan berdasarkan nilai-nilai ketuhanan atau yang bersumber dari ajaran agama yang dianutnya oleh karena itu diharapkan siswa benar-benar memahami dan 
mengamalkan ajaran dalam kehidupan seharihari. Apabila seseorang memiliki karakter yang baik terkait dengan Tuhannya maka seluruh kehidupannya pun akan menjadi lebih baik karena dalam ajaran agama tidak hanya mengajarkan untuk berhubungan baik dengan Tuhan namun juga dalam sesama.

Pengembangan karakter pada siswa tidak cukup hanya dilakukan dengan pendidikan akademik di dalam kelas. Akan tetapi, memerlukan layanan psikoedukatif berupa layanan bimbingan dan konseling. Oleh karena itu, layanan bimbingan dan konseling hendaknya diarahkan pada bagaimana membekali siswa dengan karakter religius sehingga dapat mengantarka mereka menjadi makhluk beriman dan bertaqwa kepada Tuhan Yang Maha Esa sebagaimana uraian tujuan pendidian nasional dalam Undang-Undang Nomor 20 Tahun 2003 tentang Sistem Pendidikan Nasional.

Adapun strategi layanan bimbingan dan konseling yang dapat dilakukan dalam mengembangkan karakter religius siswa adalah sebagai berikut:

1. Strategi Layanan Dasar

Dalam strategi pengembangan nilai karakter melalui layanan dasar dapat dilakukan sebagai berikut :

a. Pengumpulan need assessment (kebutuhan siswa) guna penyusunan program layanan bimbingan dan konseling dengan menyebarkan assessment baik berupa ITP (Inventori Tugas Perkembangan) dan DCM (Daftar Cek Masalah). Pada kedua instrument tersebut, selain aspek yang lain terdapat pertanyaan/pernyataan yang mengungkapkan kebutuhan siswa terkait aspek kehidupan beragama/religius. Dengan demikian, guru bimbingan dan konseling dapat mengetahui kebutuhan peserta didik dalam aspek religius dari kelima dimensinya yaitu keyakinan, peribadatan, penghayatan, pengetahuan dan pengalaman. Hal tersebut kemudian menjadi dasar dalam menentukan pemberian layanan bimbingan dan konseling terhadap peserta didik sesuai dengan kebutuhannya.

b. Layanan bimbingan klasikal dan bimbingan kelompok

Pada dasarnya layanan bimbingan klasikal dan bimbingan kelompok merupakan layanan bimbingan dan konseling yang sama, perbedaannya terletak pada jumlah sasaran peserta didik yang menerima layanan. Layanan bimbingan klasikal dan bimbingan kelompok diberikan setelah mengetahui kebutuhan siswa melalui pengumpulan need assesment. Pengembangan nilai karakter religius melalui layanan bimbingan klasikal dan bimbingan kelompok dapat dilakukan dengan berdoa setiap awal kegiatan sebagai implikasi dari dimensi keyakinan, peribadatan dan penghayatan.

c. Pengelolaan media informasi

Media informasi layanan bimbingan dan konseling dapat berupa papan bimbingan, leaflet, poster, buku saku dan media laiinya. Implementasi pengembangan nilai religius melalui media informasi dapat dilakukan dengan memuat nilai-nilai religius ke dalam media. Misalnya perintah tentang beribadah melalui poster dan materi religius melalui papan bimbingan.Strategi Layanan Peminatan dan Perencanaan Individual

2. Strategi Layanan Peminatan dan Perencanaan Individual

Layanan perencanaan individual dan peminatan sebagai layanan untuk merencanakan dan mempersiapkan masa depan peserta didik dengan memperhatikan potensi yang ada pada dirinya termasuk memperhatikan kelebihan dan kekurangan yang dimiliki. Strategi penguatan nilai karakter religius melalui layanan ini dengan menguatkan dimensi pengalaman agama. Dengan demikian, hal tersebut mendorong peserta didik untuk mengaplikasikan ajaran agama yang dianutnya dalam perencanaan masa depan dan peminatannya.

3. Strategi Layanan Responsif

Layanan responsif merupakan layanan segera yang diberikan kepada peserta didik untuk menyelesaikan permasalahan peserta didik baik secara langsung maupun tidak langsung. Pengembangan nilai karakter religius dapat diterapkan ke dalam strategi layanan responsif. Misalnya penekanan dimensi keyakinan agama dalam layanan konseling individu bagi peserta didik/konseli, atau dengan berdoa sebelum kegiatan layanan konseling kelompok dimulai sebagai implementasi dari aspek keyakinan, peribadatan dan penghayatan.

4. Strategi Dukungan Sistem

Internalisasi nilai karakter religius dalam dukungan sistem misalnya penelitian guru BK tentang penerapan nilai religius siswa di sekolah 
atau melalui kegiatan parenting dengan tema "Cara Rasulullah Mendidik Anak". Kemudian bentuk dukungan sistem yang lainnya adalah adanya kolaborasi antara guru BK dengan guru agama dan tokoh agama di lingkungan masyarakat untuk meningkatkan kesadaran dan memberikan pemahaman karakter religius kepada siswa.

\section{SIMPULAN DAN SARAN}

Karakter religius sangat dibutuhkan oleh para peserta didik untuk menghadapi degradasi moral, agar mereka mampu memiliki dan berperilaku dengan ukuran baik dan buruk yang didasarkan pada ketentuan dan ketetapan agama. Karakter religius berkaitan dengan cara manusia taat terhadap agama dan mengembangkan keimanan serta ketaqwaan. Hal ini selaras dengan tujuan utama pendidikan nasional Indonesia yang tertuang dalam UU Nomor 20 Tahun 2003.

Karakter ini tidak cukup hanya dikembangkan melalui pendidikan di dalam kelas oleh guru kelas ataupun guru mapel. Diperlukan partisipasi dari guru BK melalui berbagai layanan bimbingan dan konseling. Strategi layanan bimbingan dan konseling untuk mengembangkan karakter religius digolongkan ke dalam 4 (empat) komponen layanan, yaitu (1) layanan dasar, meliputi kegiatan asesmen kebutuhan, bimbingan klasikal, bimbingan kelompok, dan penggunaan media inovatif; (2) layanan peminatan dan perencaan individual, meliputi pembangunan komitmen peserta didik untuk tetap mengaplikasikan karakter religius di masa depan; (3) layanan responsif, berupa pelaksaan layanan konseling kelompok dan konseling individu dengan pendekatan religi; dan (4) dukungan sistem, meliputi kolaborasi antara guru bimbingan dan konseling dengan guru agama, tokoh agama dan orangtua, serta adanya penelitian tentang karakter religius oleh guru bimbingan dan konseling.

Pembahasan artikel ini masih jauh dari sempurna. Masih ada beberapa hal yang belum dibahas di sini. Bagi penulis yang selanjutnya, disarankan untuk lebih memprdalam kajian teori tentang karakter religius. Penulis/peneliti selanjutnya diharapkan dapat mengembangan media yang kreatif dan inovatif untuk mengembangkan karakter religius. Selain itu, karena karakter religius sangat krusial, maka diperlukan lagi penelitian atau informasi tentang bagaimana orang tua dan/atau masyarakt dalam mengembangkan karakter religius siswa.

\section{DAFTAR RUJUKAN}

Abdul Latif. (2007). Pendidikan Berbasis Niali Kemasyarakatan. Bandung: Refika Aditama

ASCA. (2010). Comprehensive School Program Guide. New York : Institute od Technology

Bhakti CP, Hasan SUN. et.al. Peran layanan bimbingan dan konseling komprehensif dalam pengembangan karakter cerdas anak sekolah dasar. Jurnal Konseling Komprehensif. Nov 2015 : 2 (2) : 203-11.

CNN Indonesia. (2014). Angka Aborsi di Indonesia.(http://m.cnnindonesia.com/nasio nal/20141029111311-12-8642) diakses 29 Juni 2017.

Depdiknas. (2009). Penataan Pendidikan Profesional Konselor dan Layanan bimbingan dan Konseling dalam Jalur Pendidikan Formal. Jakarta: Depdiknas.

Ditjen Pendidikan Dasar dan Menengah. (2017). Materi Umum dan Materi Pokok Bimbingan Teknik Implementasi Kurikulum 2013 SMA Tahun 2017. Jakarta : Kemendikbud

Elearning Pendidikan. (2011). Membangun Karakter Religius Pada Siswa Sekolah Dasar. dalam, (http://www.elearningpendidikan.com), diakses 29 Juni 2017.

Hidayat, Dede Rahmat. (2013). Bimbingan Konseling: Kesehatan Mental Di sekolah. Bandung : Remaja Rosda Karya.

Kartadinata, S. (2011). Menguak Tabir Bimbingan dan Konseling sebagai Upaya Pedagogis. Bandung: UPI Press.

Kemendiknas. (2010). Bahan Pelatihan : Penguatan Metodologi Pembelajaran Berdasarkan Nilai-Nilai Budaya untuk Membentuk Daya Saing dan Karakter Bangsa. Jakarta: Kemendiknas 
Kompas. (2016). Data pengguna narkoba di Indonesia.(http://kompas.com/amp/regional /read/2016/01/11/14313191). Diakses 29 Juni 2017

Lies Arifah. (2009). Implementasi Pendidikan IMTAQ di SMP Negeri 2 Bantul. Tesis: UNY.

Peraturan Menteri Pendidikan dan Kebudayaan RI Nomor 111 Tahun 2014 tentang Bimbingan dan Konseling Pada Pendidikan Dasar dan Pendidikan Menengah.
Supriatna, Mamat. (2011). Bimbingan dan Konseling Berbasis Kompetensi. Jakarta: PT Rajagrafindo Persada.

Undang-Undang Nomor 20 Tahun 2003 tentang Sistem Pendidikan Nasional 